\title{
Co-Occurrence of Hepatitis A Infection and Chronic Liver Disease
}

\author{
Tatsuo Kanda *(D), Reina Sasaki, Ryota Masuzaki, Hiroshi Takahashi, Taku Mizutani, \\ Naoki Matsumoto ${ }^{D}$, Kazushige Nirei and Mitsuhiko Moriyama
}

\author{
Division of Gastroenterology and Hepatology, Department of Medicine, Nihon University School of Medicine, \\ 30-1 Oyaguchi-kamicho, Itabashi-ku, Tokyo 173-8610, Japan; sasaki.reina@nihon-u.ac.jp (R.S.); \\ masuzaki.ryota@nihon-u.ac.jp (R.M.); hiroshi.t.215@gmail.com (H.T.); mattakunotaku1981@yahoo.co.jp (T.M.); \\ matsumoto.naoki@nihon-u.ac.jp (N.M.); nirei.kazushige@nihon-u.ac.jp (K.N.); \\ mizutani.taku@nihon-u.ac.jp (M.M.) \\ * Correspondence: kanda.tatsuo@nihon-u.ac.jp; Tel.: +81-3-3972-8111
}

Received: 10 August 2020; Accepted: 1 September 2020; Published: 2 September 2020

check for updates

\begin{abstract}
Hepatitis A virus (HAV) infection occasionally leads to a critical condition in patients with or without chronic liver diseases. Acute-on-chronic liver disease includes acute-on-chronic liver failure (ACLF) and non-ACLF. In this review, we searched the literature concerning the association between HAV infection and chronic liver diseases in PubMed. Chronic liver diseases, such as metabolic associated fatty liver disease and alcoholic liver disease, coinfection with other viruses, and host genetic factors may be associated with severe hepatitis A. It is important to understand these conditions and mechanisms. There may be no etiological correlation between liver failure and HAV infection, but there is an association between the level of chronic liver damage and the severity of acute-on-chronic liver disease. While the application of an HAV vaccination is important for preventing HAV infection, the development of antivirals against HAV may be important for preventing the development of ACLF with HAV infection as an acute insult. The latter is all the more urgent given that the lives of patients with HAV infection and a chronic liver disease of another etiology may be at immediate risk.
\end{abstract}

Keywords: HBV; HCV; HIV; acute liver failure; nonalcoholic fatty liver diseases; NASH; GRP78

\section{Introduction}

Liver failure is a common disease with high mortality, and its incidence is increasing with the use of alcohol and the prevalence of obesity and diabetes [1-3]. It has also been reported that the prognosis of acute hepatitis or acute liver injury was affected by the preexistence of chronic liver diseases and cirrhosis [1,2], extrahepatic diseases, such as metabolic, malignant, and psychiatric diseases [4], and host factors, such as older age and obesity $[3,5,6]$, although the etiology of acute insults is one of the most important risk factors for the development of severe liver diseases [1,7].

Hepatitis A virus (HAV) infection is still one of the major causes of acute hepatitis worldwide. HAV infection occasionally causes acute liver failure [4,8]. It has been reported that a superinfection of HAV in patients with a chronic hepatitis $\mathrm{C}$ virus $(\mathrm{HCV})$ infection is associated with fulminant hepatitis [9], although much research denies this association [5,10]. HAV infection rarely causes acute liver failure in patients without underlying chronic liver diseases [9].

There are excellent, safe, and effective HAV vaccines to prevent HAV infection. However, HAV vaccination costs a lot. As no universal vaccination program against HAV infection exists in certain countries, such as Japan, it may be important to develop potential drugs against HAV infection [11]. 
In this review, we searched the recent literature concerning the association between HAV infection and chronic liver diseases, including metabolic associated fatty liver disease (MAFLD), in PubMed. We also discussed the mechanism of severe acute hepatitis A.

\section{Acute-On-Chronic Liver Failure with HAV Infection as an Acute Insult}

Acute-on-chronic liver diseases include acute-on-chronic liver failure (ACLF) and non-ACLF [12]. ACLF, which presents acutely with multiple organ failure and is precipitated by an acute insult, has high short-term mortality [2,13]. In general, the prognosis of ACLF is worse than that of acute liver failure. ACLF is a distinct concept, where acute hepatic decompensation occurs in patients with chronic liver disease or cirrhosis in encountering an acute insult, leading to high short-term mortality [2]. In Asian countries, hepatitis viruses are important factors of acute insults, unlike in European countries and the United States [2], and HAV is one of the acute insults of ACLF [1,12,14-17].

HAV superinfection was found to be the most common etiology (42\%) of acute deterioration in children with ACLF in India [15]. ACLF in adults was found to be due to HEV, HAV, or both in 61\%, $27 \%$, and $6 \%$ of cases [1], respectively, although HAV infections occur in childhood, and HAV infection as an acute insult in adult ACLF is relatively uncommon in India [17]. Agrawal et al. reported an adult patient with ACLF and HAV as an acute insult who had an underlying cirrhotic liver due to nonalcoholic steatohepatitis (NASH) [17]. Among the children and adults with ACLF, acute insults caused by both HAV and HEV are important. It may be important to consider them in order to improve the prognosis of ACLF by developing a treatment for HAV infection.

\section{HAV Infection and Metabolic Associated Fatty Liver Disease (MAFLD)}

ACLF may occur among patients with chronic liver diseases or cirrhosis due to nonalcoholic fatty liver diseases (NAFLD), including NASH and alcoholic liver diseases (ALD), in eastern and western countries [2,13]. NASH is the most rapidly increasing etiology for ACLF [18]. Agrawal et al. reported a nonobese 34-year-old man presenting ACLF with acute HAV infection superimposed on NASH without cirrhosis [17] (Table 1). Kahraman et al. also reported a human immunodeficiency virus (HIV)-positive case presenting ACLF with acute HAV infection superimposed on cirrhosis due to NASH [19]. NASH is also observed among people less than 40 years old, and acute-on-chronic liver diseases may have an atypical course among these patients [20].

Table 1. Acute-on-chronic liver failure with hepatitis A virus (HAV) infection in patients with nonalcoholic steatohepatitis (NASH) or chronic alcoholic liver diseases (ALD).

\begin{tabular}{llccc}
\hline Authors (Year) [References] & N & Acute Insults & Underlying CLD & Prognosis \\
\hline Agrawal S, et al. (2018) [17] & 1 & HAV & NASH & Recovered \\
Kahraman A, et al. (2006) [19] & 1 & HAV & NASH and HIV & Died \\
Lefillatre P, et al. (2000) [21] & 1 & HAV & ALD & Died \\
Spada E, et al. (2005) [22] & 2 & HAV & ALD and HCV & Died \\
\hline CLD, chronic liver diseases; HIV, human immunodeficiency virus; ALD, alcoholic liver disease; HCV, hepatitis \\
C virus.
\end{tabular}

Fatty liver diseases associated with metabolic dysfunction are common and have a heterogeneous genetic predisposition, metabolic syndrome, and environmental factors [23]. Recently, experts suggested "MAFLD" should replace NAFLD/NASH [23]. The diagnosis of MAFLD is based on the detection of liver steatosis in the presence of overweight or obesity, diabetes mellitus, and/or clinical evidence of metabolic abnormalities, such as hypertension, dyslipidemia, and hyperglycemia.

A Japanese nationwide survey of ALF and late-onset hepatic failure (LOHF) caused by HAV infection suggested that diabetic mellitus was more common among deceased patients than among rescued patients $(29 \%$ vs. $8 \% ; p<0.05)$, excluding patients with liver transplantations, and that diabetic 
mellitus was independently associated with the outcome [24]. Patients with diabetes are at risk of developing severe hepatitis [25].

We observed that HAV HA11-1299 genotype IIIA strain replication is enhanced by the accumulation of lipids or high-concentration glucose in the human hepatoma cell line, Huh7 [26-28]. Hyperglycemia or the accumulation of lipids induces an endoplasmic reticulum (ER) stress response in human hepatocytes. HAV replicates in the ER of human hepatocytes and induces an ER stress response. The ER stress response is mediated by the sensor molecules, inositol-requiring enzyme $1 \alpha$ (IRE1 $\alpha)$, PKR-like ER kinase (PERK), and activating transcription factor 6 (ATF6), which are usually associated with molecular chaperone glucose-regulated protein 78 (GRP78) [27]. GRP78 is a negative regulator of ER stress response. We also observed that the overexpression of GRP78 could inhibit HAV replication, while the knockdown or knockout of GRP78 enhanced HAV replication [26,28]. In sum, GRP78 is an antiviral protein against HAV replication [28].

\section{HAV Infection and Alcoholic Liver Diseases (ALD)}

There are several factors affecting the severity of HAV infection and the rates of fulminant hepatic failure [29]. These important factors include older age, concomitant virus infection, chronic liver disease, sexual orientation, intravenous drug use, and alcohol abuse [6,29]. Feller et al. reported that 12 patients developed hepatic encephalopathy, ascites, or both, among 20 patients with alcoholic cirrhosis and a superimposed episode of acute viral hepatitis [30]. HAV infection was excluded in only three of these patients [30].

Lefilliatre et al. reported that three patients with fulminant hepatitis A had preexisting liver diseases, and one of the three had biopsy-proven alcoholic cirrhosis [21] (Table 1). Spada et al. reported that two individuals were HCV-coinfected alcohol abusers, had underlying liver cirrhosis, and died of acute liver failure due to HAV infection [22] (Table 1).

While the direct effects of alcohol on HAV replication is unknown, excess alcohol intake (binge drinking) could induce hepatic fibrosis. As only alcohol intake is responsible for worsening ACLF with alcoholic chronic liver diseases and alcoholic cirrhosis [31], HAV may have an additive responsibility for worsening ACLF with ALD.

\section{Coinfection of HAV with HIV}

In Japan, where no universal vaccination programs against HAV infection exist, $10-20 \%$ of those with HIV infection tested positive for immunoglobulin G (IgG) anti-hepatitis A (HA) antibodies [32-35]. This prevalence is similar to that of IgG anti-HA in those without HIV infection [36,37], although a higher prevalence area can also be observed in Japan [38]. In general, individuals of high-risk groups, such as healthcare workers, sewage workers, and drug addicts, have $\sim 60 \%$ of IgG anti-HA worldwide $[39,40]$. The seroprevalence of IgG anti-HA is relatively higher in people living with HIV worldwide [41-43].

HIV infection has also been reported as a cause of liver damage in patients infected with HIV [40]. Thus, it is as important to consider patients with HIV infection as those with chronic liver disease. Not only chronic viral hepatitis B or C but also drug-induced liver injury induced by the antiretroviral drugs, NAFLD and ALD, has also been observed in people with HIV [40].

HAV infection in patients with chronic liver diseases and coinfected with HIV are shown in Table 2 [21,22,44,45]. Prolonged HAV infection was also reported in an HIV-seropositive patient [44]. It was reported that the recovery of immunity through recently developed anti-HIV therapies may lead to more severe hepatocellular damage in patients with HAV infection [45].

HAV infects humans through fecal-oral routes, when HAV-contaminated water and food are consumed. Among men who have sex with men (MSM), HAV is sexually transmitted [46], and HAV outbreaks have been observed [47-55]. It is noteworthy that acute hepatitis A among MSM is one of the male-dominant diseases, although, in general, no gender difference exists in patients with an HAV infection caused by HAV-contaminated water and food. While HAV may cause severe hepatitis in 
people living with HIV, two doses of an HAV vaccine are more effective for them to achieve a sustained HAV seroresponse than a single dose of an HAV vaccine [56].

Table 2. Coinfection with hepatitis A virus (HAV) and human immunodeficiency virus (HIV).

\begin{tabular}{ccccc}
\hline Authors (Year) [References] & N & Acute Insults & Underlying CLD & Prognosis \\
\hline Lefillatre P, et al. (2000) [21] & 1 & HAV & HBV, HCV, and HIV & Died \\
Spada E, et al. (2005) [22] & 1 & HAV & HCV and HIV & $\begin{array}{c}\text { Died } \\
\text { Alive; HAV RNA } \\
\text { detected in 256 } \\
\text { days }\end{array}$ \\
Costa-Mattioli et al. (2002) [44] & 1 & HAV & HIV & Died \\
Maki Y, et al. (2020) [45] & 1 & HAV & HIV &
\end{tabular}

CLD, chronic liver diseases; HBV, hepatitis B virus; $\mathrm{HCV}$, hepatitis $\mathrm{C}$ virus.

\section{Coinfection of HAV with $\mathrm{HBV}$}

Several cases of ACLF with HAV as an acute insult and chronic hepatitis or cirrhosis due to $\mathrm{HBV}$, as well as cases with a superinfection of HAV in patients with HBV, have been reported (Table 3) [9,21,57-62]. A superinfection of HBsAg carriers with HAV seems not to cause more severe conditions [57]. Patients with HBV plus HAV infection had a less advanced baseline liver disease and a better prognosis than those with HBV plus hepatitis E virus infection [60].

Table 3. Acute-on-chronic liver failure and/or superinfection of hepatitis virus (HAV) in patients with hepatitis B virus (HBV).

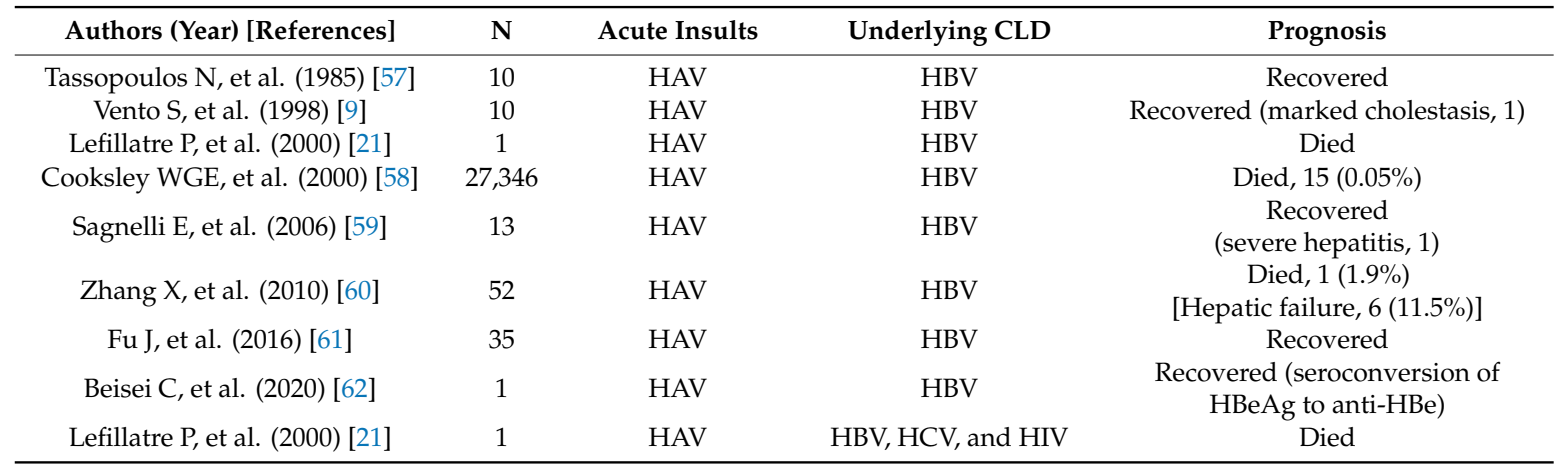

CLD, chronic liver diseases; $\mathrm{HCV}$, hepatitis $\mathrm{C}$ virus; $\mathrm{HIV}$, human immunodeficiency virus; $\mathrm{HBeAg}$, hepatitis $\mathrm{B}$ virus e antigen.

Vento et al. reported that, among 10 patients with an acquired HAV superinfection and chronic HBV infection, one (10\%), who had cirrhosis, had marked cholestasis [9]. Pramoolsinsap et al. evaluated acute superinfection with HAV in $20 \mathrm{HBV}$ asymptomatic carriers and fulminant hepatitis or submassive hepatitis in 11 (55\%) of $20 \mathrm{HBsAg}$ carriers [63]. A superinfection of HAV in patients with HBV occasionally leads to critical conditions in HBV carriers with or without cirrhosis, although patients with advanced fibrosis or cirrhosis are more susceptible to severe conditions [9,21,57-63].

A total of 310,746 cases with acute hepatitis A were observed during the Shanghai hepatitis A epidemic [58]. A total of 47 fatal cases $(0.015 \%)$ were reported. Fatality rates were $0.05 \%(15 / 27,346)$ and $0.009 \%(25 / 283,400)$ in patients with or without HBV infection, respectively. It is worth noting that there were 5.6-fold greater fatality rates in patients with HBV infection than in those without [58]. Cooksley et al. reported that patients infected with HBV who have raised ALT levels and high HBV levels have a higher risk of liver failure following HAV superinfection [58]. HAV vaccination seems to be effective in preventing liver failure associated with HAV in patients with or without HBV infection [64-67]. However, HAV vaccination may not be necessary in the case of countries in which HAV is endemic, such as India [68,69]. 
It has been reported that the transient suppression of HBV replication and the disappearance of HBV DNA with the seroconversion of HBeAg were observed in several cases of double infections with HAV and HBV carries [57]. Beisel et al. also reported that an HBsAg carrier case with HAV superinfection presented the seroconversion of $\mathrm{HBsAg}$, suggesting that unspecific immunological responses to HAV could lead to a functional cure of HBV [62]. It was reported that the sharp peak in interferon-gamma production induced by a superinfection of HAV may lead to the suppression of HBV replication in patients with chronic hepatitis B [70]. This peak in interferon-gamma production occurred just before the rise in serum transaminase activity, resulting in a decrease in HBV DNA and HBeAg.

Berthillon et al. infected the human hepatoma cell line, PLC/PRF/5 [71], which integrates HBV DNA and produces HBsAg, with the HAV CF53 strain [72]. The inhibition of HBsAg production in PLC/PRF/5 cells infected with HAV was observed, compared with those without HAV infection, demonstrating that HAV interferes with the expression of HBsAg from hepatocytes harboring integrated HBV DNA sequences [71]. We also infected HepG2.2.15, which produces HBV virion or HepG2 cells, with the HAV HA11-1299 strain. We demonstrated that the HAV replication is similar between HepG2.2.15 and HepG2, $96 \mathrm{~h}$ after HAV infection. However, HBV replication is inhibited in HAV-infected HepG2.2.15, compared to HepG2.2.15 without HAV infection [73].

We also observed that the replication of both HAV and HBV is suppressed in human hepatocyte PXB cells superinfected with HAV and HBV, compared to those mono-infected with HAV or HBV [73]. Thus, HAV infection seems to inhibit HBV replication. Further studies are required to support this point, although it indicates that the existence of cirrhosis or advanced liver fibrosis should cause severe hepatitis in the superinfection of HAV in patients with HBV.

\section{Coinfection of HAV with HCV}

In general, $\mathrm{HCV}$ is a rare cause of fulminant hepatitis or acute liver failure [74,75]. We did not identify any cases of fulminant hepatitis with HCV RNA in 82 cases of fulminant hepatitis and late-onset hepatic failure from 1986 to 2001, which were examined at Chiba University School of Medicine, Japan [74]. There were several reports that HAV infection in patients with chronic hepatitis $C$ is associated with increased mortality $[9,21,22,76]$, although several contrary opinions exist $[59,77]$ (Table 4).

Table 4. Acute-on-chronic liver failure (ACLF) and/or the superinfection of hepatitis virus (HAV) in patients with hepatitis $\mathrm{C}$ virus $(\mathrm{HCV})$.

\begin{tabular}{ccccc}
\hline Authors (Year) [References] & N & Acute Insults & Underlying CLD & Prognosis \\
\hline Vento S, et al. (1998) [9] & 17 & HAV & HCV & Recovered, 10; fulminant \\
hepatitis, 7 \\
Sagnelli E, et al. (2006) [59] & 8 & HAV & HCV & Recovered \\
Deterding K, et al. (2006) [77] & 17 & HAV & HCV & Fulminant hepatitis, 0 \\
Spada E, et al. (2005) [22] & 1 & HAV & HCV and ALD & Died \\
Spada E, et al. (2005) [22] & 1 & HAV & HCV and HIV & Died \\
Lefillatre P, et al. (2000) [21] & 1 & HAV & HBV plus HCV and HIV & Died \\
\hline
\end{tabular}

CLD, chronic liver diseases; HBV, hepatitis B virus; ALD, alcoholic liver disease; HIV, human immunodeficiency virus.

Vento et al. reported that, among 17 patients with an acquired HAV superinfection with chronic hepatitis C, seven patients (41.2\%) possessed fulminant hepatic failure, and six (85.7\%) of those seven patients died [9]. It is interesting to note that antinuclear antibodies, anti-smooth-muscle antibodies, and/or anti-asialoglycoprotein receptor antibodies were detected in five of seven patients with fulminant hepatitis (71.4\%) [9]. Moreover, six of these seven patients possessed chronic active hepatitis, and one patient recovered from fulminant hepatitis and was treated with methylprednisolone [9]. There are some reports indicating a higher fatality rate of HAV superinfection in patients with chronic HCV 
infection, not considering those with or without cirrhosis [21]. However, it is unclear whether the high fatality rates were due to severe underlying liver damage or not [21,22].

It was reported that the superinfection of HAV is associated with decreased HCV replication, which may lead to a clearance of HCV $[77,78]$. Esser-Nobis et al. found that Huh7-Lunet cells supported HAV and HCV replication with similar efficacy and limited interference with each other [79].

In fact, as several severe hepatitis A cases have been observed in patients with chronic HCV infection, clinicians should pay attention to HAV infection in HCV-infected individuals [80]. At present, although direct-acting antivirals against $\mathrm{HCV}$ can lead to a higher sustained virological response with less adverse events, no effective HCV vaccines are available. Thus, HAV vaccination should be considered for HCV-infected patients, especially those with cirrhosis or advanced fibrosis [81-88].

\section{HAV and Other Chronic Liver Diseases}

It was reported that a prospective study of 31 children in the age group of 1-16 years, who fulfilled the criteria for ACLF of the Asian Pacific Association for the Study of the Liver (APASL) 2008 consensus, found 13 ACLF cases of HAV as an acute insult and autoimmune hepatitis or Wilson disease as causes of chronic liver disease [15]. In children, acute-on-chronic liver diseases, HEV, and HAV are more frequently causes of acute insults and Wilson disease, while autoimmune liver disease and primary sclerosing cholangitis are more frequently causes of chronic liver disease [12]. It is possible that HAV infection, as an acute insult, could result in ACLF in patients with any chronic liver disease, especially cirrhosis. Careful attention should also be paid to HAV infection in adults and children who have certain chronic liver diseases.

\section{Host Genetic Factors in HAV Infection}

Acute insults in ACLF are different, depending on the country in which they are found [2]. In Asian countries, European countries, and the United States, hepatic, hepatic, and extrahepatic or infection (extrahepatic) causes, respectively, are representative acute insults in the definition of the APASL, EASL, and NACSELD ACLF guidelines [2,89-91]. Of course, not only a sanitary environment but also host genetic factors are different in these different regions. Among Mexican Americans, transforming growth factor beta 1 (TGFB1) rs1800469 (adjusted odds ratio (OR), 1.38; 95\% confidence interval $(\mathrm{CI}), 1.14-1.68$; $\mathrm{P}$ value adjusted for false discovery rate $(\mathrm{FDR}-\mathrm{P})=0.017)$ and $\mathrm{X}$-ray repair cross complementing 1 (XRCC1) rs1799782 (OR, 1.57; 95\% CI, 1.27-1.94; FDR-P $=0.0007$ ) were associated with an increased risk of HAV infection [92]. ATP-binding cassette subfamily B member 1 (ABCB1) rs1045642 (OR, 0.79; 95\% CI, 0.71-0.89; FDR-P = 0.0007) was associated with a decreased risk [92]. Host genetic factors may also play an important role in determining the differential susceptibility to HAV infection [92-94].

\section{Prevention of HAV Infection in Patients with Chronic Liver Diseases}

\subsection{HAV Vaccination}

HAV vaccination may be important for patients with chronic liver diseases, especially those with cirrhosis [81-88]. While a universal vaccination program against HAV seems to be the most effective solution for the prevention of HAV infection, it may be difficult to carry out this program worldwide due to the high costs of HAV vaccine production and its low effectiveness in certain countries in which the infection is endemic $[88,95]$. HAV vaccination targeting certain populations may also be effective and important in this regard [96]. Antivirals against HAV infection may also be needed (Figure 1). The unknown causes for chronic injury constitute only $5-15 \%$ of cases of ACLF [2]. 


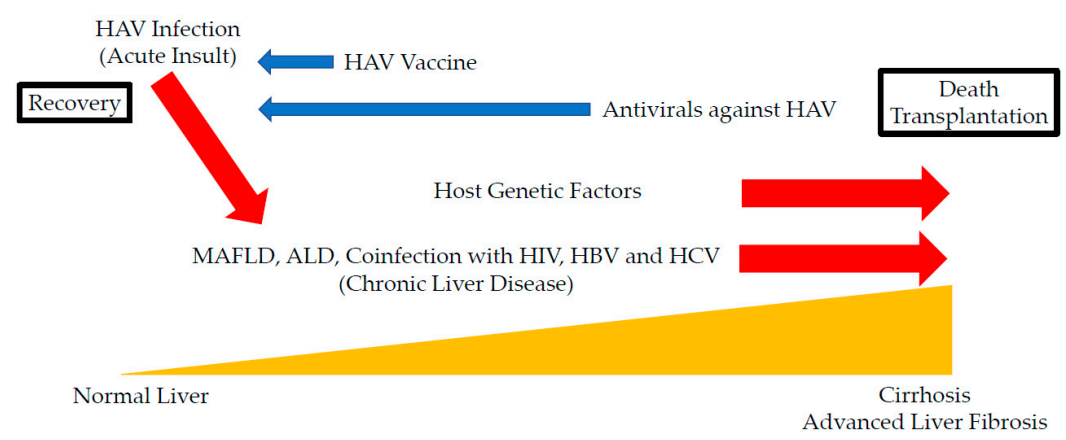

Figure 1. Effects of hepatitis A infection (HAV) on the prognosis of chronic liver disease. Possible acceleration and inhibition of the disease progression of hepatitis A are indicated by red and blue arrows, respectively. MAFLD, metabolic associated fatty liver disease; ALD, alcoholic liver disease; $\mathrm{HIV}$, human immunodeficiency virus; $\mathrm{HBV}$, hepatitis B virus; $\mathrm{HCV}$, hepatitis $\mathrm{C}$ virus.

10.2. Japanese Rice-Koji Miso Extracts and Zinc Sulfates Could Inhibit HAV Replication with the Enhancement of GRP78 Expression

Japanese rice-koji miso extracts enhanced GRP78 expression and inhibited HAV HA11-1299 genotype IIIA strain replication in the human hepatocytes, Huh7 and PXB cells [97]. We investigated the effect of miso extracts on virus replication in HepG2.2.15 cells infected with the HAV HA11-1299 strain [73]. It is noteworthy that miso extracts have an inhibitory effect on HAV replication but no inhibitory effect on HBV replication. Japanese rice-koji miso extracts may have an inhibitory effect on HAV replication in patients superinfected with HAV and HBV.

The zinc homeostasis pathway was identified as a key pathway of the antiviral activity of Japanese rice-koji miso against HAV infection using transcriptome-sequencing analysis [98]. We also demonstrated that zinc sulfate has an inhibitory effect on HAV HA11-1299 replication in human hepatocytes with the enhancement of GRP78 expression [98]. As Japanese miso soup and zinc sulfate are traditional foods and drugs, respectively, they induce GRP78 expression and are useful and safe antiviral compounds against HAV, with fewer adverse events. Gut dysbiosis and increased permeability cause pathological bacterial translocation and endotoxemia, which play an important role in the development of ACLF [2]. HAV infects the liver by the gut-portal vein-liver axis through fecal-oral routes. The digestion and absorption of Japanese rice-koji miso extracts and zinc sulfate may be used through similar routes.

\subsection{Candidates of Antivirals against HAV in Chronic Liver Diseases}

The inhibitory effects of interferon-alpha, interferon-gamma, interferon-lambda, ribavirin, amantadine, sirtinol, and AZD1480 as host-targeting drugs and HAV 3C cysteine protease inhibitors, as well as small interfering RNAs against HAV, as antivirals that directly act on HAV replication, have been reported [11,46,99]. Interferon has antiviral potential against HAV [100,101], but it is difficult to use interferon in patients with ACLF, as interferon generally has cytotoxicity. Peginterferon-lambda has fewer side effects than peginterferon-alpha and may be useful in some patients with HAV infection. Amantadine is a broad-spectrum antiviral and has an inhibitory effect on HAV replication through the targeting of HAV internal entry site (IRES) activity $[100,102,103]$. The sirtuin inhibitor, sirtinol, also inhibits HAV replication by inhibiting HAV IRES activity [104]. Further studies on the mechanism of the sirtuin inhibitor and JAK pathways in HAV replication are needed [104,105]. In patients with chronic liver diseases or ACLF, these drugs should be improved, and more safe drugs are needed and should be explored. It has been reported that HCV receptor candidates, such as HAV cellular receptor 1 (HAVcr-1), integrin $\beta 1$, and gangliosides, are the entry receptor candidates for HAV. Further studies in this vein are needed [106-108]. Gangliosides seem to function as endosome receptors for infection using both naked and quasi-enveloped HAV virions [108]. Blocking the cellular entry of HAV is also an attractive drug target for combating HAV infection. 
10.4. HAV Infection Is Associated with the Activation of the Host Immune System and Severe Systemic Inflammation

Acute hepatitis A usually exhibits more severe inflammation, such as a higher fever and higher C-reactive protein levels, compared to acute hepatitis due to other hepatitis viruses [109-111]. Some cases of acute HAV infection present acute renal failure [112-114]. These results suggest that HAV infection activates human immune systems and induces cytokines [115-119]. Innate immunity also seems to be involved in the pathogenesis of hepatitis A $[120,121]$. Hypergammaglobulinemia and a high occurrence of autoantibodies are observed in HAV infection [122,123]. This may support the immunological basis of its pathogenesis. Moreover, the higher gammaglobulinemia in fulminant HAV suggests the existence of a more aggressive immunological reaction in severe hepatitis A [123].

Severe systemic inflammation can affect the functions of somatic cells in tissue and modify the clinical manifestation of cirrhosis and ACLF [124,125]. Patients with acute liver failure or ACLF are susceptible to infection, and early transplant-free survival is poor [126-129]. In liver transplantation for patients with ACLF, the role of the timing, bridging, and management of liver transplantation is important $[130,131]$.

\subsection{Recent Outbreak of HAV Infection in MSM}

It has recently been reported that HAV susceptibility parallels the high COVID-19 mortality [132]. The 2019 coronavirus disease (COVID-19) has been observed in Japan, where the HAV susceptibility of the general population is high [34,35]. An HAV vaccination program is urgently required for individuals with or without HIV infection in this area. HAV infection is an imported infection, like novel severe acute respiratory syndrome coronavirus 2 (SARS-CoV-2) infection [133]. In the era of COVID-19, attention should also be paid to dual infection with HAV and SARS-CoV-2.

An outbreak of HAV infection in MSM has been observed worldwide. An outbreak of acute HAV infection among HIV-coinfected MSM in Taiwan was observed from June 2015 to September 2017 [50,134,135]. Between July 2016 and February 2017, 48 male cases of HAV infection were found in the Netherlands [48]. A total of 17 of them were MSM. This strain is identical to a strain causing a large outbreak among MSM in Taiwan [48]. In the United States, HAV infections also increased among MSM from 2016 to 2018 [54,136,137]. Since 2017, HAV infection has increased among MSM in Japan [34,37,52]. RIVM-HAV16-090-like hepatitis A virus strains, which were $>99.6 \%$ identical to the 66 reported strains isolated from Taiwan and European countries from 2015 to 2017, were also recovered from Japanese MSM [52]. A recent outbreak of HAV infection was also reported in various countries, such as Brazil, Spain, and Italy [53,138-140].

\section{Possible Molecular Mechanism of the Development of ACLF in Patients with HAV Infection}

The molecular mechanism of the development of ACLF in patients with HAV infection is not fully understood. The possible mechanisms of the development of liver failure in the presence of coinfection with HCV and HAV are as follows. HAV is a virus that is generally sensitive to interferon [100-102]. In comparison with HCV, HAV induces a limited production of type I interferon when HAV infects chimpanzees [141]. Compared with HBV and HCV, HAV weakly induced the activation of NF-kB signaling pathways in human hepatocytes $[142,143]$. While HAV VP3 activates cell growth signaling [143], HAV VP1/2A reduces cell viabilities in HCV sub-genomic replicon cells [144].

HAV is usually a non-cytopathic virus, and HAV inhibits double-stranded (dsRNA)-induced interferon-beta gene expression by influencing the interferon-beta enhanceosome, as well as dsRNA-induced apoptosis [145]. Compared with HBV and HCV, HAV could evade mitochondrial antiviral signaling protein (MAVS)-mediated type I interferon responses [146]. HAV 3ABC is capable of MAVS cleavage, like HCV NS3/4A, which cleaves MAVS and disrupts interferon signaling [147]. HAV 3C inhibits HAV IRES-dependent translation and cleaves the polypyrimidine tract-binding protein [148]. $\mathrm{HCV}$ induces interferon-beta signaling pathways in human hepatocytes [149]. Controlling the effects of interferon signaling may determine the prognosis of patients coinfected with HCV and HAV (Figure 2). 


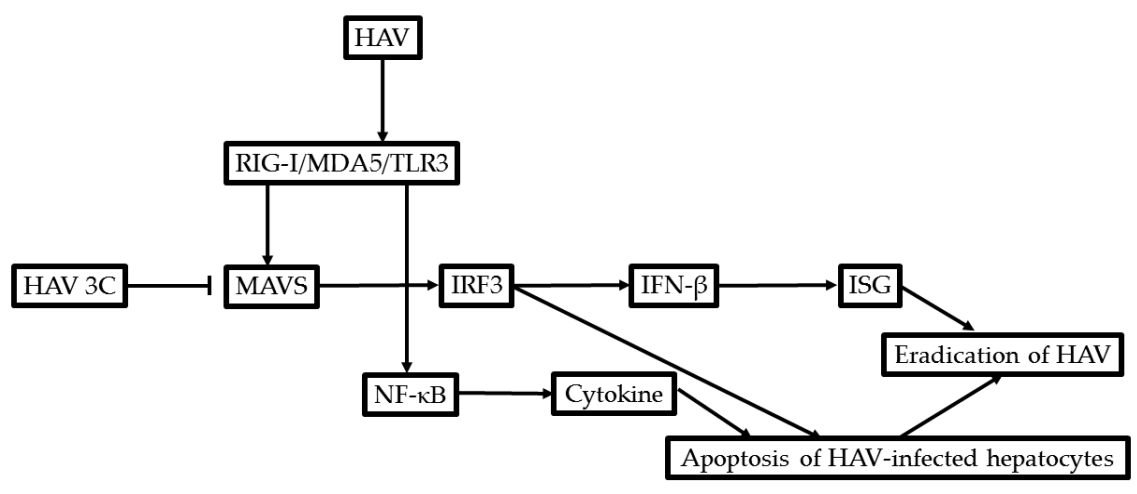

(a)

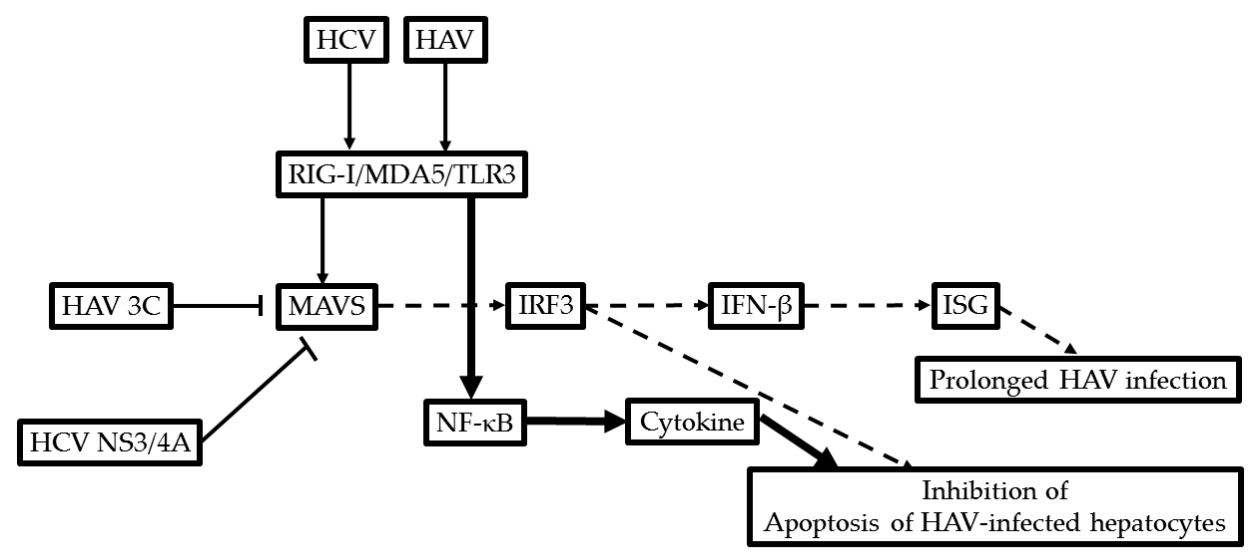

(b)

Figure 2. Possible molecular mechanism of the development of acute-on-chronic liver failure (ACLF) in patients coinfected with hepatitis A virus (HAV) and HCV. (a) Only HAV infection; (b) coinfection HAV and HCV. RIG-I, retinoic acid-inducible gene-I; MDA-5, melanoma differentiation associated gene 5; TLR3, toll-like receptor 3; MAVS, mitochondrial antiviral signaling protein; IRF3, interferon regulatory factor 3; IFN, interferon; ISG, interferon-stimulated gene; NF-kB, nuclear factor kappa B subunit 1.

$\mathrm{HBV}$ is a stealth virus which efficiently infects humans without alerting the innate immune system, although HCV strongly induces but cunningly evades the innate immune response [150]. The high glucose and fat deposition of hepatocytes seem to induce a chaperon-mediated autophagy (CMA) [151]. CMA targets interferon-alpha receptor chain-1 for degradation, dampens hepatic innate immunity, and disrupts interferon signaling pathways [151]. CMA is also observed in patients with ALD or MAFLD [152,153]. Altering interferon signaling may contribute to ALF-associated acute HAV infection. However, further studies are needed. Among HIV-positive patients with acute HAV infection, lower peaks in total bilirubin, AST, and ALT levels were observed in comparison with HIV-negative patients with acute HAV infection [154], suggesting that weaker immune responses occur in HIV-positive patients. These immune responses could enhance HAV replication and modify the pathogenesis in HIV-positive patients with acute hepatitis A [155].

\section{Conclusions}

We reviewed the literature concerning HAV infection in patients with chronic liver diseases. In patients with chronic liver diseases, HAV infection can occasionally lead to a critical condition, 
such as acute liver failure. There seems to be no etiological association between liver failure and HAV infection, but there is a significant correlation between the severity of liver disease and the degree to which the liver has already been damaged. While there are effective HAV vaccines currently in existence, antivirals against HAV should be further explored. The latter is urgent given that the lives of patients with HAV infection and a chronic liver disease of another etiology may be at immediate risk.

Author Contributions: Conceptualization, T.K., R.S. and R.M.; formal analysis, T.K.; investigation, T.K.; resources, T.K.; writing-original draft preparation, T.K.; writing-review and editing, T.K., R.S. and R.M.; supervision, H.T., T.M., N.M., K.N. and M.M.; funding acquisition, T.K. All authors have read and agreed to the published version of the manuscript.

Funding: This research was supported by the Japan Agency for Medical Research and Development (AMED), under grant number JP20fk0210075.

Conflicts of Interest: The authors declare no conflict of interest. The funders had no role in the design of the study; in the collection, analyses, or interpretation of data; in the writing of the manuscript, or in the decision to publish the results.

\section{Abbreviations}

$\begin{array}{ll}\text { HAV } & \text { Hepatitis A virus } \\ \text { HBV } & \text { Hepatitis B virus } \\ \text { HCV } & \text { Hepatitis C virus } \\ \text { MAFLD } & \text { Metabolic associated fatty liver disease } \\ \text { ACLF } & \text { Acute-on-chronic liver failure } \\ \text { NASH } & \text { Nonalcoholic steatohepatitis } \\ \text { NAFLD } & \text { Nonalcoholic fatty liver disease } \\ \text { HIV } & \text { Human immunodeficiency virus } \\ \text { LOHF } & \text { Late-onset hepatic failure } \\ \text { ER } & \text { Endoplasmic reticulum } \\ \text { IgG } & \text { Immunoglobulin } \\ \text { GRP78 } & \text { Glucose-regulated protein 78 } \\ \text { ALD } & \text { Alcoholic liver disease } \\ \text { CMA } & \text { Chaperon-mediated autophagy }\end{array}$

\section{References}

1. Radha Krishna, Y.; Saraswat, V.A.; Das, K.; Himanshu, G.; Yachha, S.K.; Aggarwal, R.; Choudhuri, G. Clinical features and predictors of outcome in acute hepatitis $\mathrm{A}$ and hepatitis $\mathrm{E}$ virus hepatitis on cirrhosis. Liver Int. 2009, 29, 392-398. [CrossRef] [PubMed]

2. Sarin, S.K.; Choudhury, A.; Sharma, M.K.; Maiwall, R.; Al Mahtab, M.; Rahman, S.; Saigal, S.; Saraf, N.; Soin, A.S.; Devarbhavi, H.; et al. Acute-on-chronic liver failure: Consensus recommendations of the Asian Pacific association for the study of the liver (APASL): An update. Hepatol. Int. 2019, 13, 353-390. [CrossRef] [PubMed]

3. Kanda, T.; Yokosuka, O.; Hiraide, A.; Kojima, H.; Honda, A.; Fukai, K.; Imazeki, F.; Nagao, K.; Saisho, H. Prevalence of obesity in patients with acute hepatitis; is severe obesity a risk factor for fulminant hepatitis in Japan? Hepatogastroenterology 2005, 52, 180-182. [PubMed]

4. Nakao, M.; Nakayama, N.; Uchida, Y.; Tomiya, T.; Ido, A.; Sakaida, I.; Yokosuka, O.; Takikawa, Y.; Inoue, K.; Genda, T.; et al. Nationwide survey for acute liver failure and late-onset hepatic failure in Japan. J. Gastroenterol. 2018, 53, 752-769. [CrossRef] [PubMed]

5. Keeffe, E.B. Is hepatitis A more severe in patients with chronic hepatitis B and other chronic liver diseases? Am. J. Gastroenterol. 1995, 90, 201-205. [PubMed]

6. Sainokami, S.; Abe, K.; Ishikawa, K.; Suzuki, K. Influence of load of hepatitis A virus on disease severity and its relationship with clinical manifestations in patients with hepatitis A. J. Gastroenterol. Hepatol. 2005, 20, 1165-1175. [CrossRef] 
7. Fujiwara, K.; Nakayama, N.; Kato, N.; Yokosuka, O.; Tsubouchi, H.; Takikawa, H.; Mochida, S.; Intractable Hepato-Biliary Diseases Study Group of Japan. Infectious complications and timing for liver transplantation in autoimmune acute liver failure in Japan: A subanalysis based on nationwide surveys between 2010 and 2015. J. Gastroenterol. 2020. [CrossRef]

8. Tominaga, A.; Kanda, T.; Akiike, T.; Komoda, H.; Ito, K.; Abe, A.; Aruga, A.; Kaneda, S.; Saito, M.; Kiyohara, T.; et al. Hepatitis A outbreak associated with a revolving sushi bar in Chiba, Japan: Application of molecular epidemiology. Hepatol. Res. 2012, 42, 828-834. [CrossRef]

9. Vento, S.; Garofano, T.; Renzini, C.; Cainelli, F.; Casali, F.; Ghironzi, G.; Ferraro, T.; Concia, E. Fulminant hepatitis associated with hepatitis A virus superinfection in patients with chronic hepatitis C. N. Engl. J. Med. 1998, 338, 286-290. [CrossRef]

10. Mele, A.; Tosti, M.E.; Stroffolini, T. Hepatitis associated with hepatitis A superinfection in patients with chronic hepatitis C. N. Engl. J. Med. 1998, 338, 1771. [CrossRef]

11. Kanda, T.; Nakamoto, S.; Wu, S.; Nakamura, M.; Jiang, X.; Haga, Y.; Sasaki, R.; Yokosuka, O. Direct-acting Antivirals and Host-targeting Agents against the Hepatitis A Virus. J. Clin. Transl. Hepatol. 2015, 3, $205-210$. [CrossRef] [PubMed]

12. Jagadisan, B.; Srivastava, A.; Yachha, S.K.; Poddar, U. Acute on chronic liver disease in children from the developing world: Recognition and prognosis. J. Pediatr. Gastroenterol. Nutr. 2012, 54, 77-82. [CrossRef] [PubMed]

13. Singal, A.K.; Kamath, P.S. Acute on chronic liver failure in non-alcoholic fatty liver and alcohol associated liver disease. Transl. Gastroenterol. Hepatol. 2019, 4, 74. [CrossRef] [PubMed]

14. Sarin, S.K.; Kumar, A.; Almeida, J.A.; Chawla, Y.K.; Fan, S.T.; Garg, H.; de Silva, H.J.; Hamid, S.S.; Jalan, R.; Komolmit, P.; et al. Acute-on-chronic liver failure: Consensus recommendations of the Asian Pacific Association for the study of the liver (APASL). Hepatol. Int. 2009, 3, 269-282. [CrossRef] [PubMed]

15. Lal, J.; Thapa, B.R.; Rawal, P.; Ratho, R.K.; Singh, K. Predictors of outcome in acute-on-chronic liver failure in children. Hepatol. Int. 2011, 5, 693-697. [CrossRef]

16. Kumar, A.; Saraswat, V.A. Hepatitis E and Acute-on-Chronic Liver Failure. J. Clin. Exp. Hepatol. 2013, 3, 225-230. [CrossRef]

17. Agrawal, S.; Rana, B.S.; Mitra, S.; Duseja, A.; Das, A.; Dhiman, R.K.; Chawla, Y. A Case of Acute-on-Chronic Liver Failure (ACLF) Due to An Uncommon Acute and Chronic Event. J. Clin. Exp. Hepatol. 2018, 8, $95-97$. [CrossRef]

18. Axley, P.; Ahmed, Z.; Arora, S.; Haas, A.; Kuo, Y.F.; Kamath, P.S.; Singal, A.K. NASH Is the Most Rapidly Growing Etiology for Acute-on-Chronic Liver Failure-Related Hospitalization and Disease Burden in the United States: A Population-Based Study. Liver Transpl. 2019, 25, 695-705. [CrossRef]

19. Kahraman, A.; Miller, M.; Gieseler, R.K.; Gerken, G.; Scolaro, M.J.; Canbay, A. Non-alcoholic fatty liver disease in HIV-positive patients predisposes for acute-on-chronic liver failure: Two cases. Eur. J. Gastroenterol. Hepatol. 2006, 18, 101-105. [CrossRef]

20. Kanda, T.; Yokosuka, O.; Suzuki, Y. Prolonged hepatitis caused by cytomegalovirus and non-alcoholic steatohepatitis in 16-year-old obese boy. Eur. J. Pediatr. 2005, 164, 212-215. [CrossRef]

21. Lefilliatre, P.; Villeneuve, J.P. Fulminant hepatitis A in patients with chronic liver disease. Can. J. Public Health 2000, 91, 168-170. [CrossRef] [PubMed]

22. Spada, E.; Genovese, D.; Tosti, M.E.; Mariano, A.; Cuccuini, M.; Proietti, L.; Giuli, C.D.; Lavagna, A.; Crapa, G.E.; Morace, G.; et al. An outbreak of hepatitis A virus infection with a high case-fatality rate among injecting drug users. J. Hepatol. 2005, 43, 958-964. [CrossRef] [PubMed]

23. Eslam, M.; Sanyal, A.J.; George, J. International Consensus Panel. MAFLD: A Consensus-Driven Proposed Nomenclature for Metabolic Associated Fatty Liver Disease. Gastroenterology 2020, 158, 1999-2014.e1. [CrossRef] [PubMed]

24. Nakao, M.; Nakayama, N.; Uchida, Y.; Tomiya, T.; Oketani, M.; Ido, A.; Tsubouchi, H.; Takikawa, H.; Mochida, S. Deteriorated outcome of recent patients with acute liver failure and late-onset hepatic failure caused by infection with hepatitis A virus: A subanalysis of patients seen between 1998 and 2015 and enrolled in nationwide surveys in Japan. Hepatol. Res. 2019, 49, 844-852. [CrossRef] [PubMed]

25. Singh, K.K.; Panda, S.K.; Shalimar Acharya, S.K. Patients with Diabetes Mellitus are Prone to Develop Severe Hepatitis and Liver Failure due to Hepatitis Virus Infection. J. Clin. Exp. Hepatol. 2013, 3, 275-280. [CrossRef] [PubMed] 
26. Win, N.N.; Kanda, T.; Nakamura, M.; Nakamoto, S.; Okamoto, H.; Yokosuka, O.; Shirasawa, H. Free fatty acids or high-concentration glucose enhances hepatitis A virus replication in association with a reduction in glucose-regulated protein 78 expression. Biochem. Biophys. Res. Commun. 2017, 483, 694-699. [CrossRef]

27. Jiang, X.; Kanda, T.; Nakamoto, S.; Haga, Y.; Sasaki, R.; Nakamura, M.; Wu, S.; Mikata, R.; Yokosuka, O. Knockdown of glucose-regulated protein 78 enhances poly(ADP-ribose) polymerase cleavage in human pancreatic cancer cells exposed to endoplasmic reticulum stress. Oncol. Rep. 2014, 32, 2343-2348. [CrossRef]

28. Jiang, X.; Kanda, T.; Haga, Y.; Sasaki, R.; Nakamura, M.; Wu, S.; Nakamoto, S.; Shirasawa, H.; Okamoto, H.; Yokosuka, O. Glucose-regulated protein 78 is an antiviral against hepatitis A virus replication. Exp. Ther. Med. 2017, 13, 3305-3308. [CrossRef]

29. O'Grady, J.G. Fulminant hepatitis in patients with chronic liver disease. J. Viral Hepat. 2000, 7, 9-10. [CrossRef]

30. Feller, A.; Uchida, T.; Rakela, J. Acute viral hepatitis superimposed on alcoholic liver cirrhosis: Clinical and histopathologic features. Liver 1985, 5, 239-246. [CrossRef]

31. Duseja, A.; Chawla, Y.K.; Dhiman, R.K.; Kumar, A.; Choudhary, N.; Taneja, S. Non-hepatic insults are common acute precipitants in patients with acute on chronic liver failure (ACLF). Dig. Dis. Sci. 2010, 55, 3188-3192. [CrossRef] [PubMed]

32. Kiyosawa, K.; Oofusa, H.; Saitoh, H.; Sodeyama, T.; Tanaka, E.; Furuta, S.; Itoh, S.; Ogata, H.; Kobuchi, H.; Kameko, M.; et al. Seroepidemiology of hepatitis A, B, and D viruses and human T-lymphocyte tropic viruses in Japanese drug abusers. J. Med. Virol. 1989, 29, 160-163. [CrossRef] [PubMed]

33. Hayashi, K.; Fukuda, Y.; Nakano, I.; Katano, Y.; Nagano, K.; Yokozaki, S.; Hayakawa, T.; Toyoda, H.; Takamatsu, J. Infection of hepatitis A virus in Japanese haemophiliacs. J. Infect. 2001, 42, 57-60. [CrossRef] [PubMed]

34. Koibuchi, T.; Koga, M.; Kikuchi, T.; Horikomi, T.; Kawamura, Y.; Lim, L.A.; Adachi, E.; Tsutsumi, T.; Yotsuyanagi, H. Prevalence of Hepatitis a Immunity and Decision-tree Analysis Among Men Who Have Sex With Men and Are Living With Human Immunodeficiency Virus in Tokyo. Clin. Infect. Dis. 2020, 71, 473-479. [CrossRef]

35. Yan, J.; Kanda, T.; Wu, S.; Imazeki, F.; Yokosuka, O. Hepatitis A, B, C and E virus markers in Chinese residing in Tokyo, Japan. Hepatol. Res. 2012, 42, 974-981. [CrossRef]

36. Yamamoto, C.; Ko, K.; Nagashima, S.; Harakawa, T.; Fujii, T.; Ohisa, M.; Katayama, K.; Takahashi, K.; Okamoto, H.; Tanaka, J. Very low prevalence of anti-HAV in Japan: High potential for future outbreak. Sci. Rep. 2019, 9, 1493. [CrossRef]

37. Koga, M.; Lim, L.A.; Ogishi, M.; Satoh, H.; Kikuchi, T.; Adachi, E.; Sugiyama, R.; Kiyohara, T.; Suzuki, R.; Muramatsu, M.; et al. Comparison of the Clinical Features of Hepatitis A in People Living with HIV between Pandemics in 1999-2000 and 2017-2018 in the Metropolitan Area of Japan. Jpn. J. Infect. Dis. 2020, 73, 89-95. [CrossRef]

38. Akao, T.; Onji, M.; Kawasaki, K.; Uehara, T.; Kuwabara, Y.; Nishimoto, T.; Yamamoto, S.; Miyaike, J.; Oomoto, M.; Miyake, T. Surveillance of Hepatitis Viruses in Several Small Islands of Japan by Ship: A Public Health Approach for Elimination of Hepatitis Viruses by 2030. Euroasian J. Hepatogastroenterol. 2019, 9, 57-62. [CrossRef]

39. Franco, E.; Giambi, C.; Ialacci, R.; Coppola, R.C.; Zanetti, A.R. Risk groups for hepatitis A virus infection. Vaccine 2003, 21, 2224-2233. [CrossRef]

40. Puoti, M.; Moioli, M.C.; Travi, G.; Rossotti, R. The burden of liver disease in human immunodeficiency virus-infected patients. Semin. Liver Dis. 2012, 32, 103-113. [CrossRef]

41. O'Riordan, M.; Goh, L.; Lamba, H. Increasing hepatitis A IgG prevalence rate in men who have sex with men attending a sexual health clinic in London: Implications for immunization policy. Int. J. STD AIDS 2007, 18, 707-710. [CrossRef] [PubMed]

42. Sadlier, C.; O'Rourke, A.; Carr, A.; Bergin, C. Seroepidemiology of hepatitis A, hepatitis B and varicella virus in people living with HIV in Ireland. J. Infect. Public Health 2017, 10, 888-890. [CrossRef] [PubMed]

43. Cohall, A.; Zucker, J.; Krieger, R.; Scott, C.; Guido, C.; Hakala, S.; Carnevale, C. Missed Opportunities for Hepatitis A Vaccination Among MSM Initiating PrEP. J. Community Health 2020, 45, 506-509. [CrossRef] [PubMed]

44. Costa-Mattioli, M.; Allavena, C.; Poirier, A.S.; Billaudel, S.; Raffi, F.; Ferré, V. Prolonged hepatitis A infection in an HIV-1 seropositive patient. J. Med. Virol. 2002, 68, 7-11. [CrossRef] [PubMed] 
45. Maki, Y.; Kimizuka, Y.; Sasaki, H.; Yamamoto, T.; Hamakawa, Y.; Tagami, Y.; Miyata, J.; Hayashi, N.; Fujikura, Y.; Kawana, A. Hepatitis A virus-associated fulminant hepatitis with human immunodeficiency virus coinfection. J. Infect. Chemother. 2020, 26, 282-285. [CrossRef]

46. Kanda, T.; Sasaki, R.; Masuzaki, R.; Matsumoto, N.; Ogawa, M.; Moriyama, M. Cell Culture Systems and Drug Targets for Hepatitis A Virus Infection. Viruses 2020, 12, 533. [CrossRef]

47. Beebeejaun, K.; Degala, S.; Balogun, K.; Simms, I.; Woodhall, S.C.; Heinsbroek, E.; Crook, P.D.; Kar-Purkayastha, I.; Treacy, J.; Wedgwood, K.; et al. Outbreak of hepatitis A associated with men who have sex with men (MSM), England, July 2016 to January 2017. Euro. Surveill. 2017, 22, 30454. [CrossRef]

48. Freidl, G.S.; Sonder, G.J.; Bovée, L.P.; Friesema, I.H.; van Rijckevorsel, G.G.; Ruijs, W.L.; van Schie, F.; Siedenburg, E.C.; Yang, J.Y.; Vennema, H. Hepatitis A outbreak among men who have sex with men (MSM) predominantly linked with the EuroPride, the Netherlands, July 2016 to February 2017. Euro. Surveill. 2017, 22, 30468. [CrossRef]

49. Comelli, A.; Izzo, I.; Casari, S.; Spinetti, A.; Bergamasco, A.; Castelli, F. Hepatitis A outbreak in men who have sex with men (MSM) in Brescia (Northern Italy), July 2016-July 2017. Infez. Med. 2018, 26, 46-51.

50. Cheng, C.Y.; Wu, H.H.; Zou, H.; Lo, Y.C. Epidemiological characteristics and associated factors of acute hepatitis A outbreak among HIV-coinfected men who have sex with men in Taiwan, June 2015-December 2016. J. Viral. Hepat. 2018, 25, 1208-1215. [CrossRef]

51. Boucher, A.; Meybeck, A.; Alidjinou, K.; Huleux, T.; Viget, N.; Baclet, V.; Valette, M.; Alcaraz, I.; Sauser, E.; Bocket, L.; et al. Clinical and virological features of acute hepatitis A during an ongoing outbreak among men who have sex with men in the North of France. Sex. Transm. Infect. 2019, 95, 75-77. [CrossRef]

52. Watanabe, S.; Morimoto, N.; Miura, K.; Takaoka, Y.; Nomoto, H.; Tsukui, M.; Isoda, N.; Ohnishi, H.; Nagashima, S.; Takahashi, M.; et al. Full-genome characterization of the RIVM-HAV16-090-like hepatitis A virus strains recovered from Japanese men who have sex with men, with sporadic acute hepatitis A. Hepatol. Res. 2019, 49, 521-530. [CrossRef] [PubMed]

53. Lombardi, A.; Rossotti, R.; Moioli, M.C.; Merli, M.; Valsecchi, P.; Zuccaro, V.; Vecchia, M.; Grecchi, C.; Patruno, S.F.A.; Sacchi, P.; et al. The impact of HIV infection and men who have sex with men status on hepatitis A infection: The experience of two tertiary centres in Northern Italy during the 2017 outbreak and in the 2009-2016 period. J. Viral Hepat. 2019, 26, 761-765. [CrossRef] [PubMed]

54. Foster, M.A.; Hofmeister, M.G.; Kupronis, B.A.; Lin, Y.; Xia, G.L.; Yin, S.; Teshale, E. Increase in Hepatitis A Virus Infections-United States, 2013-2018. MMWR Morb. Mortal. Wkly. Rep. 2019, 68, 413-415. [CrossRef] [PubMed]

55. Raczyńska, A.; Wickramasuriya, N.N.; Kalinowska-Nowak, A.; Garlicki, A.; Bociaga-Jasik, M. Acute Hepatitis A Outbreak Among Men Who Have Sex With Men in Krakow, Poland; February 2017-February 2018. Am. J. Mens. Health 2019, 13, 1557988319895141. [CrossRef]

56. Tsai, P.H.; Tsai, M.S.; Chiang, Y.H.; Shih, C.Y.; Liu, C.Y.; Chuang, Y.C.; Yang, C.J. Effectiveness of hepatitis A vaccination among people living with HIV in Taiwan: Is one dose enough? J. Microbiol. Immunol. Infect. 2020. [CrossRef]

57. Tassopoulos, N.; Papaevangelou, G.; Roumeliotou-Karayannis, A.; Kalafatas, P.; Engle, R.; Gerin, J.; Purcell, R.H. Double infections with hepatitis A and B viruses. Liver 1985, 5, 348-353. [CrossRef]

58. Cooksley, W.G. What did we learn from the Shanghai hepatitis A epidemic? J. Viral Hepat. 2000, 7, 1-3. [CrossRef]

59. Sagnelli, E.; Coppola, N.; Pisaturo, M.; Pisapia, R.; Onofrio, M.; Sagnelli, C.; Catuogno, A.; Scolastico, C.; Piccinino, F.; Filippini, P. Clinical and virological improvement of hepatitis B virus-related or hepatitis C virus-related chronic hepatitis with concomitant hepatitis A virus infection. Clin. Infect. Dis. 2006, 42, 1536-1543. [CrossRef]

60. Zhang, X.; Ke, W.; Xie, J.; Zhao, Z.; Xie, D.; Gao, Z. Comparison of effects of hepatitis E or A viral superinfection in patients with chronic hepatitis B. Hepatol. Int. 2010, 4, 615-620. [CrossRef]

61. Fu, J.; Gao, D.; Huang, W.; Li, Z.; Jia, B. Clinical analysis of patients suffering from chronic hepatitis B superinfected with other hepadnaviruses. J. Med. Virol. 2016, 88, 1003-1009. [CrossRef] [PubMed]

62. Beisei, C.; Addo, M.M.; Schulze Zur Wiesch, J. Seroconversion of HBsAG coincides with hepatitis A super-infection: A case report. World J. Clin. Cases 2020, 8, 1651-1655. [CrossRef] [PubMed] 
63. Pramoolsinsap, C.; Poovorawan, Y.; Hirsch, P.; Busagorn, N.; Attamasirikul, K. Acute, hepatitis-A super-infection in HBV carriers, or chronic liver disease related to HBV or HCV. Ann. Trop. Med. Parasitol. 1999, 93, 745-751. [CrossRef] [PubMed]

64. Sung, J.J.Y. Epidemiology of hepatitis A in Asia and experience with the HAV vaccine in Hong Kong. J. Viral Hepat. 2000, 7 (Suppl. 1), 27-28. [CrossRef] [PubMed]

65. Tsang, S.W.; Sung, J.J. Inactivated hepatitis A vaccine in Chinese patients with chronic hepatitis B infection. Aliment. Pharmacol. Ther. 1999, 13, 1445-1449. [CrossRef] [PubMed]

66. Locarnini, S. A virological perspective on the need for vaccination. J. Viral Hepat. 2000, 7, 5-6. [CrossRef]

67. Kurata, R.; Kodama, Y.; Takamura, N.; Gomi, H. Hepatitis A in a human immunodeficiency virus-infected patient: Impending risk during the Tokyo Olympic Games in 2020. J. Infect. Chemother. 2020. [CrossRef]

68. Joshi, N.; Rao, S.; Kumar, A.; Patil, S.; Rani, S. Hepatitis A vaccination in chronic liver disease: Is it really required in a tropical country like India? Indian J. Med. Microbiol. 2007, 25, 137-139. [CrossRef]

69. Anand, A.C.; Nagpal, A.K.; Seth, A.K.; Dhot, P.S. Should one vaccinate patients with chronic liver disease for hepatitis A virus in India? J. Assoc. Physicians India 2004, 52, 785-787.

70. Van Nunen, A.B.; Pontesilli, O.; Uytdehaag, F.; Osterhaus, A.D.; de Man, R.A. Suppression of hepatitis B virus replication mediated by hepatitis A-induced cytokine production. Liver 2001, 21, 45-49. [CrossRef]

71. Berthillon, P.; Crance, J.M.; Leveque, F.; Jouan, A.; Petit, M.A.; Deloince, R.; Trepo, C. Inhibition of the expression of hepatitis A and B viruses (HAV and $\mathrm{HBV}$ ) proteins by interferon in a human hepatocarcinoma cell line (PLC/PRF/5). J. Hepatol. 1996, 25, 15-19. [CrossRef]

72. Ishii, T.; Tamura, A.; Shibata, T.; Kuroda, K.; Kanda, T.; Sugiyama, M.; Mizokami, M.; Moriyama, M. Analysis of HBV Genomes Integrated into the Genomes of Human Hepatoma PLC/PRF/5 Cells by HBV Sequence Capture-Based Next-Generation Sequencing. Genes 2020, 11, 661. [CrossRef] [PubMed]

73. Win, N.N.; Kanda, T.; Ogawa, M.; Nakamoto, S.; Haga, Y.; Sasaki, R.; Nakamura, M.; Wu, S.; Matsumoto, N.; Matsuoka, S.; et al. Superinfection of hepatitis A virus in hepatocytes infected with hepatitis B virus. Int. J. Med. Sci. 2019, 16, 1366-1370. [CrossRef] [PubMed]

74. Kanda, T.; Yokosuka, O.; Imazeki, F.; Saisho, H. Acute hepatitis C virus infection, 1986-2001: A rare cause of fulminant hepatitis in Chiba, Japan. Hepatogastroenterology 2004, 51, 556-558.

75. Villamil, F.G.; Hu, K.Q.; Yu, C.H.; Lee, C.H.; Rojter, S.E.; Podesta, L.G.; Makowka, L.; Geller, S.A.; Vierling, J.M. Detection of hepatitis $C$ virus with RNA polymerase chain reaction in fulminant hepatic failure. Hepatology 1995, 22, 1379-1386.

76. Vento, S. Fulminant hepatitis associated with hepatitis A virus superinfection in patients with chronic hepatitis C. J. Viral Hepat. 2000, 7, 7-8. [CrossRef]

77. Deterding, K.; Tegtmeyer, B.; Cornberg, M.; Hadem, J.; Potthoff, A.; Böker, K.H.; Tillmann, H.L.; Manns, M.P.; Wedemeyer, H. Hepatitis A virus infection suppresses hepatitis $C$ virus replication and may lead to clearance of HCV. J. Hepatol. 2006, 45, 770-778. [CrossRef]

78. Cacopardo, B.; Nunnari, G.; Nigro, L. Clearance of HCV RNA following acute hepatitis A superinfection. Dig. Liver Dis. 2009, 41, 371-374. [CrossRef]

79. Esser-Nobis, K.; Harak, C.; Schult, P.; Kusov, Y.; Lohmann, V. Novel perspectives for hepatitis A virus therapy revealed by comparative analysis of hepatitis $C$ virus and hepatitis A virus RNA replication. Hepatology 2015, 62, 397-408. [CrossRef]

80. Sagnelli, E.; Sagnelli, C.; Pisaturo, M.; Coppola, N. Hepatic flares in chronic hepatitis C: Spontaneous exacerbation vs hepatotropic viruses superinfection. World J. Gastroenterol. 2014, 20, 6707-6715. [CrossRef]

81. Koff, R.S. Risks associated with hepatitis A and hepatitis B in patients with hepatitis C. J. Clin. Gastroenterol. 2001, 33, 20-26. [CrossRef] [PubMed]

82. Devalle, S.; de Paula, V.S.; de Oliveira, J.M.; Niel, C.; Gaspar, A.M. Hepatitis A virus infection in hepatitis C Brazilian patients. J. Infect. 2003, 47, 125-128. [CrossRef]

83. Shim, M.; Khaykis, I.; Park, J.; Bini, E.J. Susceptibility to hepatitis A in patients with chronic liver disease due to hepatitis C virus infection: Missed opportunities for vaccination. Hepatology 2005, 42, 688-695. [CrossRef]

84. Ramsay, D.B.; Friedman, M.; Borum, M.L. Does the race or gender of hepatitis C infected patients influence physicians' assessment of hepatitis A and hepatitis B serologic status? South Med. J. 2007, 100, 683-685. [CrossRef] [PubMed] 
85. Villar, L.M.; de Melo, M.M.; Calado, I.A.; de Almeida, A.J.; Lampe, E.; Gaspar, A.M. Should Brazilian patients with chronic hepatitis $\mathrm{C}$ virus infection be vaccinated against hepatitis A virus? J. Gastroenterol. Hepatol. 2009, 24, 238-242. [CrossRef] [PubMed]

86. Buxton, J.A.; Kim, J.H. Hepatitis A and hepatitis B vaccination responses in persons with chronic hepatitis C infections: A review of the evidence and current recommendations. Can. J. Infect. Dis. Med. Microbiol. 2008, 19, 197-202. [CrossRef] [PubMed]

87. Kramer, J.R.; Hachem, C.Y.; Kanwal, F.; Mei, M.; El-Serag, H.B. Meeting vaccination quality measures for hepatitis A and B virus in patients with chronic hepatitis C infection. Hepatology 2011, 53, 42-52. [CrossRef]

88. Rowe, I.A.; Parker, R.; Armstrong, M.J.; Houlihan, D.D.; Mutimer, D.J. Hepatitis A virus vaccination in persons with hepatitis $C$ virus infection: Consequences of quality measure implementation. Hepatology 2012, 56, 501-506. [CrossRef]

89. Sarin, S.K.; Kedarisetty, C.K.; Abbas, Z.; Amarapurkar, D.; Bihari, C.; Chan, A.C.; Chawla, Y.K.; Dokmeci, A.K.; Garg, H.; Ghazinyan, H.; et al. Acute-on-chronic liver failure: Consensus recommendations of the Asian Pacific Association for the Study of the Liver (APASL) 2014. Hepatol. Int. 2014, 8, 453-471. [CrossRef]

90. Arroyo, V.; Moreau, R.; Jalan, R.; Ginès, P. EASL-CLIF Consortium CANONIC Study. Acute-on-chronic liver failure: A new syndrome that will re-classify cirrhosis. J. Hepatol. 2015, 62, S131-S143. [CrossRef]

91. O'Leary, J.G.; Reddy, K.R.; Garcia-Tsao, G.; Biggins, S.W.; Wong, F.; Fallon, M.B.; Subramanian, R.M.; Kamath, P.S.; Thuluvath, P.; Vargas, H.E.; et al. NACSELD acute-on-chronic liver failure (NACSELD-ACLF) score predicts 30-day survival in hospitalized patients with cirrhosis. Hepatology 2018, 67, 2367-2374. [CrossRef] [PubMed]

92. Zhang, L.; Yesupriya, A.; Hu, D.J.; Chang, M.H.; Dowling, N.F.; Ned, R.M.; Udhayakumar, V.; Lindegren, M.L.; Khudyakov, Y. Variants in ABCB1, TGFB1, and XRCC1 genes and susceptibility to viral hepatitis A infection in Mexican Americans. Hepatology 2012, 55, 1008-1018. [CrossRef] [PubMed]

93. Kashyap, P.; Deka, M.; Medhi, S.; Dutta, S.; Kashyap, K.; Kumari, N. Association of Toll-like receptor 4 with hepatitis A virus infection in Assam. Acta. Virol. 2018, 62, 58-62. [CrossRef] [PubMed]

94. Rubicz, R.; Yolken, R.; Drigalenko, E.; Carless, M.A.; Dyer, T.D.; Kent, J., Jr.; Curran, J.E.; Johnson, M.P.; Cole, S.A.; Fowler, S.P.; et al. Genome-wide genetic investigation of serological measures of common infections. Eur. J. Hum. Genet. 2015, 23, 1544-1548. [CrossRef]

95. Hundekar, S.; Thorat, N.; Gurav, Y.; Lole, K. Viral excretion and antibody titers in children infected with hepatitis A virus from an orphanage in western India. J. Clin. Virol. 2015, 73, 27-31. [CrossRef] [PubMed]

96. Brouwer, A.F.; Zelner, J.L.; Eisenberg, M.C.; Kimmins, L.; Ladisky, M.; Collins, J.; Eisenberg, J.N.S. The Impact of Vaccination Efforts on the Spatiotemporal Patterns of the Hepatitis A Outbreak in Michigan, 2016-2018. Epidemiology 2020, 31, 628-635. [CrossRef] [PubMed]

97. Win, N.N.; Kanda, T.; Nakamoto, S.; Moriyama, M.; Jiang, X.; Suganami, A.; Tamura, Y.; Okamoto, H.; Shirasawa, H. Inhibitory effect of Japanese rice-koji miso extracts on hepatitis A virus replication in association with the elevation of glucose-regulated protein 78 expression. Int. J. Med. Sci. 2018, 15, 1153-1159. [CrossRef]

98. Ogawa, M.; Kanda, T.; Suganami, A.; Nakamoto, S.; Win, N.N.; Tamura, Y.; Nakamura, M.; Matsuoka, S.; Yokosuka, O.; Kato, N.; et al. Antiviral activity of zinc sulfate against hepatitis A virus replication. Future Virol. 2019, 14, 399-406. [CrossRef]

99. Cao, L.; Liu, P.; Yang, P.; Gao, Q.; Li, H.; Sun, Y.; Zhu, L.; Lin, J.; Su, D.; Rao, Z.; et al. Structural basis for neutralization of hepatitis A virus informs a rational design of highly potent inhibitors. PLoS Biol. 2019, 17, e3000229. [CrossRef]

100. Yang, L.; Kiyohara, T.; Kanda, T.; Imazeki, F.; Fujiwara, K.; Gauss-Müller, V.; Ishii, K.; Wakita, T.; Yokosuka, O. Inhibitory effects on HAV IRES-mediated translation and replication by a combination of amantadine and interferon-alpha. Virol. J. 2010, 7, 212. [CrossRef]

101. Kanda, T.; Wu, S.; Kiyohara, T.; Nakamoto, S.; Jiang, X.; Miyamura, T.; Imazeki, F.; Ishii, K.; Wakita, T.; Yokosuka, O. Interleukin-29 suppresses hepatitis A and C viral internal ribosomal entry site-mediated translation. Viral Immunol. 2012, 25, 379-386. [CrossRef] [PubMed]

102. Kanda, T.; Yokosuka, O.; Imazeki, F.; Fujiwara, K.; Nagao, K.; Saisho, H. Amantadine inhibits hepatitis A virus internal ribosomal entry site-mediated translation in human hepatoma cells. Biochem. Biophys. Res. Commun. 2005, 331, 621-629. [CrossRef] [PubMed] 
103. Kanda, T.; Imazeki, F.; Nakamoto, S.; Okitsu, K.; Fujiwara, K.; Yokosuka, O. Internal ribosomal entry-site activities of clinical isolate-derived hepatitis A virus and inhibitory effects of amantadine. Hepatol. Res. 2010, 40, 415-423. [CrossRef] [PubMed]

104. Kanda, T.; Sasaki, R.; Nakamoto, S.; Haga, Y.; Nakamura, M.; Shirasawa, H.; Okamoto, H.; Yokosuka, O. The sirtuin inhibitor sirtinol inhibits hepatitis A virus (HAV) replication by inhibiting HAV internal ribosomal entry site activity. Biochem. Biophys. Res. Commun. 2015, 466, 567-571. [CrossRef]

105. Jiang, X.; Kanda, T.; Nakamoto, S.; Saito, K.; Nakamura, M.; Wu, S.; Haga, Y.; Sasaki, R.; Sakamoto, N.; Shirasawa, H.; et al. The JAK2 inhibitor AZD1480 inhibits hepatitis A virus replication in Huh7 cells. Biochem. Biophys. Res. Commun. 2015, 458, 908-912. [CrossRef]

106. Kaplan, G.; Totsuka, A.; Thompson, P.; Akatsuka, T.; Moritsugu, Y.; Feinstone, S.M. Identification of a surface glycoprotein on African green monkey kidney cells as a receptor for hepatitis A virus. EMBO J. 1996, 15, 4282-4296. [CrossRef]

107. Rivera-Serrano, E.E.; González-López, O.; Das, A.; Lemon, S.M. Cellular entry and uncoating of naked and quasi-enveloped human hepatoviruses. Elife 2019, 8, e43983. [CrossRef]

108. Das, A.; Barrientos, R.; Shiota, T.; Madigan, V.; Misumi, I.; McKnight, K.L.; Sun, L.; Li, Z.; Meganck, R.M.; $\mathrm{Li}, \mathrm{Y}$.; et al. Gangliosides are essential endosomal receptors for quasi-enveloped and naked hepatitis A virus. Nat. Microbiol. 2020. [CrossRef]

109. Miura, Y.; Kanda, T.; Yasui, S.; Takahashi, K.; Haga, Y.; Sasaki, R.; Nakamura, M.; Wu, S.; Nakamoto, S.; Arai, M.; et al. Hepatitis A virus genotype IA-infected patient with marked elevation of aspartate aminotransferase levels. Clin. J. Gastroenterol. 2017, 10, 52-56. [CrossRef]

110. Tsukada, R.; Ono, S.; Kobayashi, H.; Wada, Y.; Nishizawa, K.; Fujii, M.; Takeuchi, M.; Kuroiwa, K.; Kobayashi, Y.; Ishii, K.; et al. A Cluster of Hepatitis A Infections Presumed to be Related to Asari Clams and Investigation of the Spread of Viral Contamination from Asari Clams. Jpn. J. Infect. Dis. 2019, 72, 44-48. [CrossRef]

111. Kogiso, T.; Sagawa, T.; Oda, M.; Yoshiko, S.; Kodama, K.; Taniai, M.; Tokushige, K. Characteristics of acute hepatitis A virus infection before and after 2001: A hospital-based study in Tokyo, Japan. J. Gastroenterol. Hepatol. 2019, 34, 1836-1842. [CrossRef] [PubMed]

112. Yoshida, Y.; Okada, Y.; Suzuki, A.; Kakisaka, K.; Miyamoto, Y.; Miyasaka, A.; Takikawa, Y.; Nishizawa, T.; Okamoto, H. Fatal acute hepatic failure in a family infected with the hepatitis A virus subgenotype IB: A case report. Medicine 2017, 96, e7847. [CrossRef] [PubMed]

113. Bajpai, M.; Kakkar, B.; Patale, D. Role of high-volume plasma exchange in a case of a G6PD deficient patient presenting with HAV related acute liver failure and concomitant acute renal failure. Transfus. Apher. Sci. 2019, 58, 102677. [CrossRef] [PubMed]

114. Kim, J.D.; Cho, E.J.; Ahn, C.; Park, S.K.; Choi, J.Y.; Lee, H.C.; Kim, D.Y.; Choi, M.S.; Wang, H.J.; Kim, I.H.; et al. A Model to Predict 1-Month Risk of Transplant or Death in Hepatitis A-Related Acute Liver Failure. Hepatology 2019, 70, 621-629. [CrossRef] [PubMed]

115. Sung, P.S.; Hong, S.H.; Lee, J.; Park, S.H.; Yoon, S.K.; Chung, W.J.; Shin, E.C. CXCL10 is produced in hepatitis A virus-infected cells in an IRF3-dependent but IFN-independent manner. Sci. Rep. 2017, 7, 6387. [CrossRef]

116. Trujillo-Ochoa, J.L.; Corral-Jara, K.F.; Charles-Niño, C.L.; Panduro, A.; Fierro, N.A. Conjugated Bilirubin Upregulates TIM-3 Expression on CD4(+)CD25(+) T Cells: Anti-Inflammatory Implications for Hepatitis A Virus Infection. Viral Immunol. 2018, 31, 223-232. [CrossRef]

117. Choi, Y.S.; Jung, M.K.; Lee, J.; Choi, S.J.; Choi, S.H.; Lee, H.W.; Lee, J.J.; Kim, H.J.; Ahn, S.H.; Lee, D.H.; et al. Tumor Necrosis Factor-producing T-regulatory Cells Are Associated With Severe Liver Injury in Patients With Acute Hepatitis A. Gastroenterology 2018, 154, 1047-1060. [CrossRef]

118. Belkaya, S.; Michailidis, E.; Korol, C.B.; Kabbani, M.; Cobat, A.; Bastard, P.; Lee, Y.S.; Hernandez, N.; Drutman, S.; de Jong, Y.P.; et al. Inherited IL-18BP deficiency in human fulminant viral hepatitis. J. Exp. Med. 2019, 216, 1777-1790. [CrossRef]

119. Jouanguy, E. Human genetic basis of fulminant viral hepatitis. Hum. Genet. 2020, 139, 877-884. [CrossRef]

120. Kim, J.; Chang, D.Y.; Lee, H.W.; Lee, H.; Kim, J.H.; Sung, P.S.; Kim, K.H.; Hong, S.H.; Kang, W.; Lee, J.; et al. Innate-like Cytotoxic Function of Bystander-Activated CD8(+) T Cells Is Associated with Liver Injury in Acute Hepatitis A. Immunity 2018, 48, 161-173.e5. [CrossRef]

121. Feng, Z.; Lemon, S.M. Innate Immunity to Enteric Hepatitis Viruses. Cold Spring Harb. Perspect. Med. 2019, 9, a033464. [CrossRef] [PubMed] 
122. Mikata, R.; Yokosuka, O.; Imazeki, F.; Fukai, K.; Kanda, T.; Saisho, H. Prolonged acute hepatitis A mimicking autoimmune hepatitis. World J. Gastroenterol. 2005, 11, 3791-3793. [CrossRef] [PubMed]

123. Abdel-Ghaffar, T.Y.; Sira, M.M.; Sira, A.M.; Salem, T.A.; El-Sharawy, A.A.; El Naghi, S. Serological markers of autoimmunity in children with hepatitis A: Relation to acute and fulminant presentation. Eur. J. Gastroenterol. Hepatol. 2015, 27, 1161-1169. [CrossRef]

124. Albillos, A.; Lario, M.; Álvarez-Mon, M. Cirrhosis-associated immune dysfunction: Distinctive features and clinical relevance. J. Hepatol. 2014, 61, 1385-1396. [CrossRef] [PubMed]

125. Ji, D.; Zhang, D.; Yang, T.; Mu, J.; Zhao, P.; Xu, J.; Li, C.; Cheng, G.; Wang, Y.; Chen, Z.; et al. Effect of COVID-19 on patients with compensated chronic liver diseases. Hepatol. Int. 2020, 1-10. [CrossRef]

126. Arai, M.; Imazeki, F.; Yonemitsu, Y.; Kanda, T.; Fujiwara, K.; Fukai, K.; Watanabe, A.; Sato, T.; Oda, S.; Yokosuka, O. Opportunistic infection in the patients with acute liver failure: A report of three cases with one fatality. Clin. J. Gastroenterol. 2009, 2, 420-424. [CrossRef] [PubMed]

127. Arai, M.; Kanda, T.; Yasui, S.; Fujiwara, K.; Imazeki, F.; Watanabe, A.; Sato, T.; Oda, S.; Yokosuka, O. Opportunistic infection in patients with acute liver failure. Hepatol. Int. 2014, 8, 233-239. [CrossRef]

128. Yasui, S.; Fujiwara, K.; Haga, Y.; Nakamura, M.; Mikata, R.; Arai, M.; Kanda, T.; Oda, S.; Yokosuka, O. Infectious complications, steroid use and timing for emergency liver transplantation in acute liver failure: Analysis in a Japanese center. J. Hepato-Biliary-Pancreat Sci. 2016, 23, 756-762. [CrossRef]

129. Doycheva, I.; Thuluvath, P.J. Acute-on-chronic liver failure in liver transplant candidates with non-alcoholic steatohepatitis. Transl. Gastroenterol. Hepatol. 2020, 5, 38. [CrossRef]

130. Trebicka, J.; Sundaram, V.; Moreau, R.; Jalan, R.; Arroyo, V. Liver Transplantation for Acute-on-Chronic Liver Failure: Science or Fiction? Liver Transpl. 2020, 26, 906-915. [CrossRef]

131. Sundaram, V.; Mahmud, N.; Perricone, G.; Katarey, D.; Wong, R.J.; Karvellas, C.J.; Fortune, B.E.; Rahimi, R.S.; Maddur, H.; Jou, J.H.; et al. Long-term outcomes of patients undergoing liver transplantation for acute-on-chronic liver failure. Liver Transpl. 2020. [CrossRef] [PubMed]

132. Meyer, A.; Regunath, H.; Rojas-Moreno, C.; Salzer, W.; Christensen, G. Imported Infections in Rural Mid-West United States-A Report from a Tertiary Care Center. Mo. Med. 2020, 117, 89-94. [PubMed]

133. SarialİoĞlu, F.; Belen, F.B.; Hayran, K.M. Hepatitis A susceptibility parallels high COVID-19 mortality. Turk. J. Med. Sci. 2020. [CrossRef]

134. Chen, G.J.; Lin, K.Y.; Sun, H.Y.; Sheng, W.H.; Hsieh, S.M.; Huang, Y.C.; Cheng, A.; Liu, W.C.; Hung, C.C.; Chang, S.C. Incidence of acute hepatitis A among HIV-positive patients during an outbreak among MSM in Taiwan: Impact of HAV vaccination. Liver Int. 2018, 38, 594-601. [CrossRef]

135. Chen, W.C.; Chiang, P.H.; Liao, Y.H.; Huang, L.C.; Hsieh, Y.J.; Chiu, C.M.; Lo, Y.C.; Yang, C.H.; Yang, J.Y. Outbreak of hepatitis A virus infection in Taiwan, June 2015 to September 2017. Euro. Surveill. 2019, 24, 1800133. [CrossRef]

136. Campos-Outcalt, D. CDC provides advice on recent hepatitis A outbreaks. J. Fam. Pract. 2018, 67, 30-32.

137. Latash, J.; Dorsinville, M.; Del Rosso, P.; Antwi, M.; Reddy, V.; Waechter, H.; Lawler, J.; Boss, H.; Kurpiel, P.; Backenson, P.B.; et al. Notes from the Field: Increase in Reported Hepatitis A Infections Among Men Who Have Sex with Men - New York City, January-August 2017. MMWR Morb. Mortal. Wkly. Rep. 2017, 66, 999-1000. [CrossRef]

138. Fraile, M.; Barreiro Alonso, E.; de la Vega, J.; Rodríguez, M.; García-López, R.; Rodríguez, M. Acute hepatitis due to hepatitis A virus during the 2017 epidemic expansion in Asturias. Spain. Med. Clin. 2019, 152, 391-394. [CrossRef]

139. Mello, V.M.; Lago, B.V.; Sousa, P.S.F.; Mello, F.C.A.; Souza, C.B.; Pinto, L.C.M.; Ginuino, C.F.; Fernandes, C.A.S.; Aguiar, S.F.; Villar, L.M.; et al. Hepatitis A Strain Linked to the European Outbreaks During Gay Events between 2016 and 2017, Identified in a Brazilian Homosexual Couple in 2017. Viruses 2019, 11, 281. [CrossRef]

140. Minosse, C.; Messina, F.; Garbuglia, A.R.; Meschi, S.; Scognamiglio, P.; Capobianchi, M.R.; Ippolito, G.; Lanini, S. Origin of HAV strains responsible for 2016-2017 outbreak among MSM: Viral phylodynamics in Lazio region. PLoS ONE 2020, 15, e0234010. [CrossRef]

141. Lanford, R.E.; Feng, Z.; Chavez, D.; Guerra, B.; Brasky, K.M.; Zhou, Y.; Yamane, D.; Perelson, A.S.; Walker, C.M.; Lemon, S.M. Acute hepatitis A virus infection is associated with a limited type I interferon response and persistence of intrahepatic viral RNA. Proc. Natl. Acad. Sci. USA 2011, 108, 11223-11228. [CrossRef] 
142. Kato, N.; Yoshida, H.; Ono-Nita, S.K.; Kato, J.; Goto, T.; Otsuka, M.; Lan, K.; Matsushima, K.; Shiratori, Y.; Omata, M. Activation of intracellular signaling by hepatitis B and C viruses: C-viral core is the most potent signal inducer. Hepatology 2000, 32, 405-412. [CrossRef]

143. Kanda, T.; Yokosuka, O.; Kato, N.; Imazeki, F.; Fujiwara, K.; Kawai, S.; Saisho, H.; Omata, M. Hepatitis A virus VP3 may activate serum response element associated transcription. Scand. J. Gastroenterol. 2003, 38, 307-313. [CrossRef] [PubMed]

144. Kanda, T.; Yokosuka, O.; Imazeki, F.; Saisho, H. Hepatitis A protein VP1-2A reduced cell viability in Huh-7 cells with hepatitis C virus subgenomic RNA replication. J. Gastroenterol. Hepatol. 2006, 21, 625-626. [CrossRef] [PubMed]

145. Brack, K.; Berk, I.; Magulski, T.; Lederer, J.; Dotzauer, A.; Vallbracht, A. Hepatitis A virus inhibits cellular antiviral defense mechanisms induced by double-stranded RNA. J. Virol. 2002, 76, 11920-11930. [CrossRef]

146. Hirai-Yuki, A.; Hensley, L.; McGivern, D.R.; González-López, O.; Das, A.; Feng, H.; Sun, L.; Wilson, J.E.; $\mathrm{Hu}, \mathrm{F}$; Feng, Z.; et al. MAVS-dependent host species range and pathogenicity of human hepatitis A virus. Science 2016, 353, 1541-1545. [CrossRef] [PubMed]

147. Yang, Y.; Liang, Y.; Qu, L.; Chen, Z.; Yi, M.; Li, K.; Lemon, S.M. Disruption of innate immunity due to mitochondrial targeting of a picornaviral protease precursor. Proc. Natl. Acad. Sci. USA 2007, 104, 7253-7258. [CrossRef] [PubMed]

148. Kanda, T.; Gauss-Müller, V.; Cordes, S.; Tamura, R.; Okitsu, K.; Shuang, W.; Nakamoto, S.; Fujiwara, K.; Imazeki, F.; Yokosuka, O. Hepatitis A virus (HAV) proteinase $3 \mathrm{C}$ inhibits HAV IRES-dependent translation and cleaves the polypyrimidine tract-binding protein. J. Viral Hepat. 2010, 17, 618-623. [CrossRef]

149. Kanda, T.; Steele, R.; Ray, R.; Ray, R.B. Hepatitis C virus infection induces the beta interferon signaling pathway in immortalized human hepatocytes. J. Virol. 2007, 81, 12375-12381. [CrossRef]

150. Wieland, S.F.; Chisari, F.V. Stealth and cunning: Hepatitis B and hepatitis C viruses. J. Virol. 2005, 79, 9369-9380. [CrossRef]

151. Dash, S.; Aydin, Y.; Moroz, K. Chaperone-Mediated Autophagy in the Liver: Good or Bad? Cells 2019, 8, 1308. [CrossRef] [PubMed]

152. You, Y.; Li, W.Z.; Zhang, S.; Hu, B.; Li, Y.X.; Li, H.D.; Tang, H.H.; Li, Q.W.; Guan, Y.Y.; Liu, L.X.; et al. SNX10 mediates alcohol-induced liver injury and steatosis by regulating the activation of chaperone-mediated autophagy. J. Hepatol. 2018, 69, 129-141. [CrossRef] [PubMed]

153. Angelini, G.; Castagneto Gissey, L.; Del Corpo, G.; Giordano, C.; Cerbelli, B.; Severino, A.; Manco, M.; Basso, N.; Birkenfeld, A.L.; Bornstein, S.R.; et al. New insight into the mechanisms of ectopic fat deposition improvement after bariatric surgery. Sci. Rep. 2019, 9, 17315. [CrossRef]

154. Ida, S.; Tachikawa, N.; Nakajima, A.; Daikoku, M.; Yano, M.; Kikuchi, Y.; Yasuoka, A.; Kimura, S.; Oka, S. Influence of human immunodeficiency virus type 1 infection on acute hepatitis A virus infection. Clin. Infect. Dis. 2002, 34, 379-385. [CrossRef]

155. Lin, K.Y.; Chen, G.J.; Lee, Y.L.; Huang, Y.C.; Cheng, A.; Sun, H.Y.; Chang, S.Y.; Liu, C.E.; Hung, C.C. Hepatitis A virus infection and hepatitis A vaccination in human immunodeficiency virus-positive patients: A review. World J. Gastroenterol. 2017, 23, 3589-3606. [CrossRef] [PubMed]

(C) 2020 by the authors. Licensee MDPI, Basel, Switzerland. This article is an open access article distributed under the terms and conditions of the Creative Commons Attribution (CC BY) license (http://creativecommons.org/licenses/by/4.0/). 